\title{
The Phenomenon of Online Shopping in the Digital Age: Why Do People Like It?
}

\author{
Mohamad Suharto ${ }^{1}$, Deny Tri Ardhianto ${ }^{2}$, Anugrah Irfan Ismail ${ }^{3}$, Nadia Sigi Prameswari ${ }^{4}$ \\ ${ }^{123}$ Faculty of Art and Design, Universitas Sebelas Maret, Surakarta \\ ${ }^{4}$ Faculty of Teacher Training and Education, Universitas Sebelas Maret, Surakarta
}

vicom4client@gmail.com (Mohamad Suharto), denytherockies@gmail.com (Deny Tri Ardhianto), irfaniax@gmail.com (Anugrah Irfan Ismail), nadiasigi87@gmail.com (Nadia Sigi Prameswari)

\begin{abstract}
The purpose of this study is to explain what factors influence consumers like to shop online. The concept underlying this study is the phenomenon of online shopping as a behaviors transformation that occurred in Indonesia. Not only in Indonesia, online shopping has spread to many countries along with the development of e-commerce business. It can be concluded that some factors influencing most consumers to like shopping online are: the visual appeal of e-commerce web design, interactive website features, the ease of the website's user interface, the corporate identity design, and the brand positioning of e-commerce companies.
\end{abstract}

Keywords Online shopping, e-commerce, web design

\section{Introduction}

The rapid digital age makes the development of Information and Communication Technology (ICT) has spread into every corner of life including business and commerce [1]. The ability of websites to send various data such as text, graphics, images, sounds, animation, or even video make many businesses that utilize commercial website technology to promote their business or called e-commerce [2].

The development of e-commerce in the world has almost reached US \$ 840 billion in 2014, sales have exceeded US \$ 695 billion in 2013, and is expected to increase to US $\$ 1506$ billion by 2018 . The increase in sales continues to indicate that e-commerce has a huge market potential. The journey and success of e-commerce retailers such as Alibaba, Tenecent, Amazon, Groupon, etc. have been set as an example for corporate who are able to shift their business model from brick-and-mortar store to brick-and-click store [3].

Online shopping behaviours have spread to many countries. Online buyers in the United States are expected to spend $\$ 371$ billion by 2016, up $41 \%$ from 2013 [4]. It is also common in Taiwan. In 2014, $61.7 \%$ of Taiwanese people bought goods online, even many parents have experience using online shopping sites [5]. Online shopping in Indonesia is evolving fast. Almost all Indonesian people even from middle class to upper class know how to conduct shopping online. This is supported by advances in technology and information media. Currently, the ease of internet access is unquestionable. People can easily use their various technology tools to access websites of online shopping.

In general, the average transaction of every online user in Indonesia has reached US \$ 68.3 per year or US \$ 5.69 per month. Based on these data, the Indonesian e-commerce industry is predicted to grow exponentially in line with the growth of Indonesian internet users [7]. Based on these conditions, the formulation of the problem can be drawn as follows: Why do people like to shopping online?

\section{Methods}

Creswell [8] described the research with a qualitative approach, which in this case is based on case studies, the research on single entity or phenomenon (case) of a particular time and activity (can be a program, event, process, institution or social group), through the collection of detailed information by using various data collection procedures during the case. This study focuses on visual studies related to e-commerce website design using a case study approach to e-commerce companies that ranked the top 3 in Indonesia based on alexa.com, namely: Tokopedia (ranked 8th), Bukalapak (ranked 12th), and Lazada (ranked 14th). The rating is assessed based on visitor traffic statistics on a website where the data is stored and analysed and updated every day by Alexa, then judged by rank for each site. 


\section{E-Commerce and Online Shopping Behaviours}

E-commerce is a modern business that meets organization's needs and customers can purchase products in a certain condition such as when prices get lower, the quality of goods increases, as well as the speed of delivery service increases. There are four types of e-commerce: business to business, business to consumer, consumer to business and consumer to consumer [9]. The benefit of using e-commerce is that customers can see the price, colour, and any size they want to buy conveniently and without wasting a lot of time [10].

Online shopping has become behaviour in Indonesia. It is a transaction processes both the sale and purchase of goods or services through the internet where the sellers and buyers do not meet physically in the transaction. Goods and services are offered through the display with images on the website or virtual store. The availability of information and attractive website design can encourage someone to purchase goods online. Now, online shopping is not unfamiliar to everyday life, both for active internet users and non-active users.

\section{Results and Discussions}

\subsection{E-Commerce Web Strength in Attracting Consum- ers}

The era of digitalization makes almost all transactions can be done online. From year to year, the number of online stores in Indonesia is growing significantly. This is in line with the increasing number of consumers who make online shopping transactions. As stated by Tanjung and Dhewanto [12], the average transaction of every online user in Indonesia has reached US $\$ 68.3$ per year or US $\$ 5.69$ per month. Based on these data, the Indonesian e-commerce industry is predicted to grow exponentially in line with the growth of Indonesian internet users. Some e-commerce companies which have been ranked as the top 3 in Indonesia on alexa.com site are Tokopedia (ranked 8th), Bukalapak (ranked 12th), and Lazada (ranked 14th).Online shopping has been a phenomenon and habits until now. Some strength of e-commerce websites that are able to change the transformation of online shopping behaviors are:

\subsubsection{The visual appeal of e-commerce web design}

E-commerce web design plays an important role because it is able to provide visual appeal for visitors. The visual appeal is an attraction that concerns the look of design, layout, and color composition. The stunning display of web designs becomes a major force to influence visitors to explore e-commerce sites even further. The beauty of an e-commerce web visualization can provide a positive image, thus increasing the confidence of visitors to buy products offered. Here is the look of e-commerce web design from Tokopedia as an e-commerce company in Indonesia which is ranked highest Alexa (www.alexa.com, 2017).

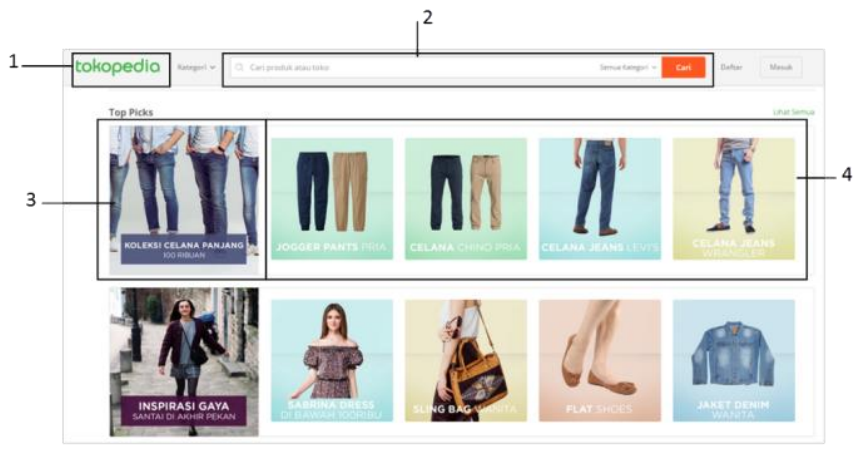

Figure 1. Tokopedia Home Page

Remarks: 1. the company logo printed on the header section serves as a corporate identity; 2 . Product or store search features and product categories; 3 . the product category comes with subcategories.

\subsubsection{The interactive website features more visitors}

Completeness of interactive e-commerce web features can provide attractiveness and attention to visitors as well as generate curiosity about the information in it. Most e-commerce sites place an interactive web banner slider on the home page as a promotional space.

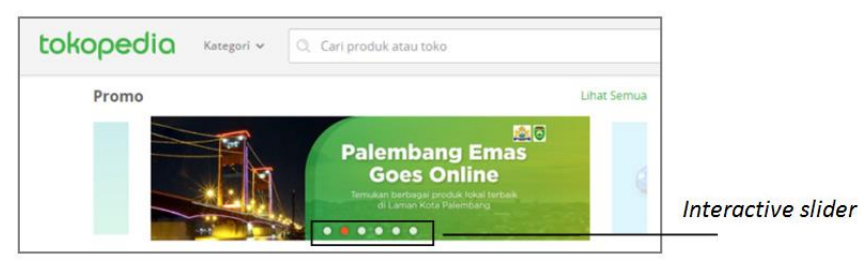

Figure 2. Web banner sliding on the home page of Tokopedia sites

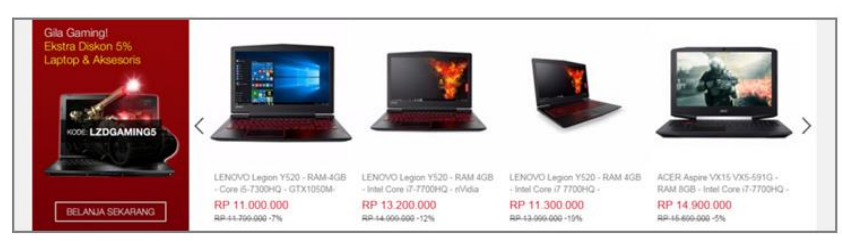

Figure 3. Interactive slider on the hompage of Tokopedia

\subsubsection{Ease of user interface design (UI) on the website}

Ease of use of the user interface can provide its own convenience to the e-commerce site visitors. Website users need a convenient user interface [13], which achieves high levels of ergonomics. Ergonomics includes the concept of efficiency in interaction with website interface design. If the website interface is designed based on the principle of usability, then the user can navigate the website comfortably [14]. 


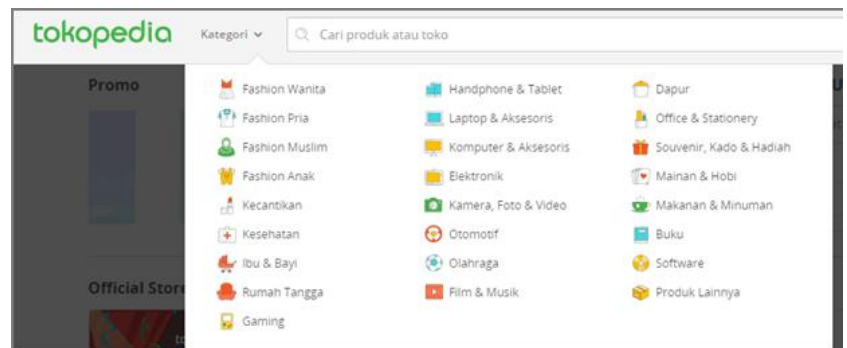

Figure 4. Tokopedia website interface design makes it easy to search product categories.

The design of the Tokopedia website user interface promotes women's fashion. E-commerce users are mostly women. Some researchers suggest that women are less competent in using the Internet than men [15]. Women have much higher anxiety about using the Internet than men [16]. Further research yielded findings that men stated a more satisfying online shopping experience than women [17].

\subsubsection{Corporate identity design}

The corporate identity colors of the three e-commerce sites: Tokopedia, Bukalapak, and Lazada differ from each other. Tokopedia uses Green color as corporate identity. The Green color is relatively more neutral, the effect on the emotions is almost passive. The Green color represents contemplation, growth, and freshness [18]. Meanwhile Bukalapak is more highlighting the color red. The color red is the color of the most attention. Meanwhile, Lazada highlights the color of the Old Blue as the color of corporate identity. Blue color has the characteristics of calm and passive. Color is a characteristic brand amplifier. No less important is the color effect on the convenience (user experience) website visitors. Illustration of Tokopedia's corporate identity tends to emphasize the vector illustration, and to make the logo logo as the visual key. The illustration of Bukalapak and Lazada corporate identity tends to emphasize photography and there is no special visual key.

\section{อิtokopedia}

Figure 5. Tokopedia Logo and Character Design
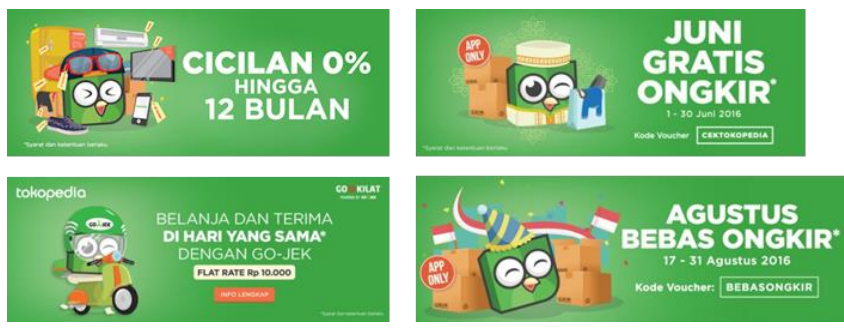

Figure 6. Character Logo as a Visual Key on Tokopedia Corporate Identity Design

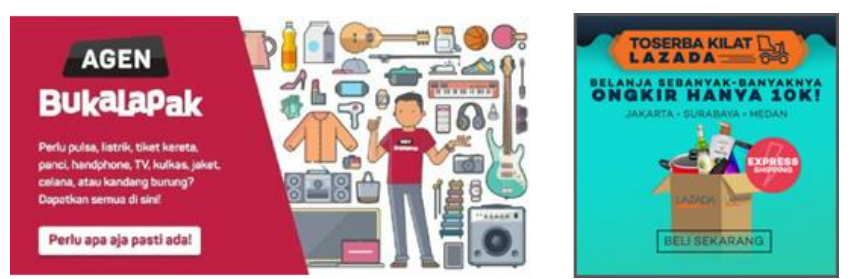

Figure 7. Corporate Identity Design Bukalapak and Lazada (left to right)

\subsection{Brand positioning of e-commerce companies}

According to Tom Duncan [19] the definition of brand position is the status of a brand compared to its competitors in the minds of customers, prospects and other shareholders. The three e-commerce sites that ranked highest in Alexa have a brand positioning strategy that is not much different from each other. Tokopedia positions itself as an e-commerce provider of a complete range of products and services. It can be seen from Tokopedia advertisements that feature illustrations of various products or services, such as air tickets, sports equipment, gadgets, and electronics with all the ease of getting it in Tokopedia.

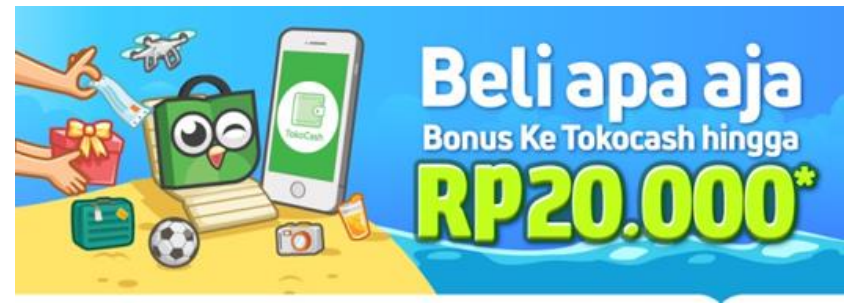

Figure 8. Tokopedia promotional ad

Not much different from Tokopedia, Bukalapak also positioned itself as an e-commerce provider of various needs of goods and services ranging from gadgets, airline tickets, trains, and electricity and pulse payments.

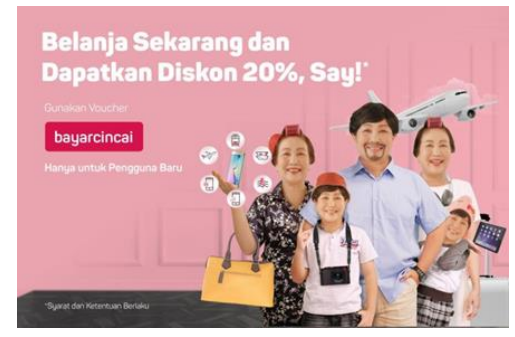

Figure 9. Bukalapak promotional advertisement

In contrast to Tokopedia and Bukalapak, Lazada sites tend to feature gadgets or el-ectronic products.

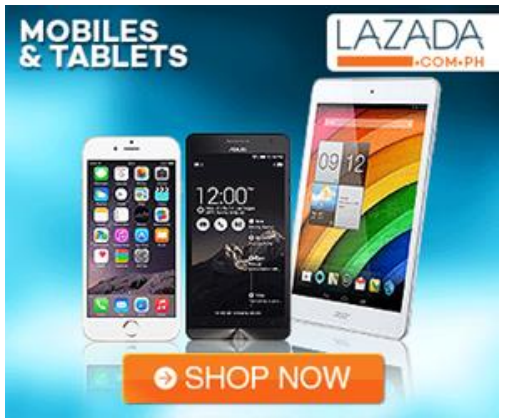

Figure 10. Lazada Promotional Ads 


\section{Conclusion}

It can be deduced that some of the factors that make the most of people love online shopping are: (1) the visual appeal of ecommerce web design. The beauty of the visualization of an e-commerce web is able to provide a positive image, thus increasing the visitor's confidence to buy the products on offer. (2) Completeness of interactive e-commerce web features can provide attractiveness and attention for visitors and generate curiosity about the information in it. (3) The ease of the user interface on the website can provide its own convenience to the visitors of e-commerce sites. (4) Visualization of corporate identity design of an e-commerce company able to provide perception and formation of corporate image in the minds of buyers. (5) Brand positioning plays a role to show the status of an e-commerce company compared to competitors in the minds of customers, prospects and other shareholders.

\section{ACKNOWLEDGEMENT}

This research is supported and funded by LPPM Universitas Sebelas Maret in Science and Technology grant for Society.

\section{REFERENCES}

[1] Fensel, D. et all. 2001. Product Data Integration in B2B E-commerce, IEEE Intelligent Systems.

[2] Bodendorf, Freimut and Florian Lang. 2009.Automated Services for Market-Based E-Commerce Transactions. Proceedings of the International MultiConference of Engineers and Computer Scientists 2009 Vol I IMECS 2009, March 18 20, 2009, Hong Kong.

[3] Lim, Yi Jin, Osman, Abdullah, Nizam, Salahuddin Shahrul, Abdullah, Safizal \& Romle, Abdul Rahim, 2016, Factors Influencing Online Shopping Behavior: The Mediating Role of Purchase Intention, Procedia Economics and Finance 35, pp. $401-410$.

[4] Aljukhadar, Muhammad \& Senecal, Sylvain, 2016, The User Multifaceted Expertise: Divergent Effects of The Website Versus E-Commerce Expertise, International Journal of Information Management, Volume 36, pp. 322-332.

[5] Wang, Chao-Hung, Chiang, Yi-Chen \& Wang, Mao-Jiun, 2013, Evaluation of an Augmented Reality Embedded On-line Shopping System, Procedia Manufacturing, Volume 3, 2015, pp. 5624-5630.

[6] Amanusa, Andro Kurnia, Astuti, Endang Siti \& Susilo, Heru, 2015, Pengaruh Kemudahan Serta Kualitas Informasi Terhadap Minat dan Penggunaan Situs Jual Beli Online (Studi Pada Pegguna Situs Jual Beli Berniaga.Com), Jurnal Administrasi Bisnis (JAB), Vol. 3, No. 1, pp. 1-8

[7] Tanjung, Farid Aulia \& Dhewanto, Wawan, 2013, Formulation of E-Commerce Website Development Plan Using Multidimensional Approach for Web Evaluation, Procedia - Social and Behavioral Sciences 115 ( 2014 ) 361 - 372.

[8] Creswell, J.W. 2007. Qualitative Inquiry and Research Design Choosing Among Five Approaches, USA: Sage Publication.
[9] Salehi, Farhang, Abdollahbeigi, Bentolhoda, Langroudi, Atefeh Charmchian \& Salehi, Forouz, 2012, The Impact of Website Information Convenience On E-commerce Success Of Companies, Social and Behavioral Sciences, Volume 57, pp. $381-387$.

[10] Şehirli, Eftâl \& Orak, İlhami M., 2014, E-Commerce According To Hobby, Social and Behavioral Sciences, Volume 143, pp. $1144-1147$

[11] Widyanto, Ibnu \& Prasilowati, Sri Lestari, 2015, Perilaku Pembelian Melalui Internet, JMK, Vol. 17, No. 2, September 2015, pp. 109-112.

[12] Tanjung, Farid Aulia \& Dhewanto, Wawan, 2013, Formulation of E-Commerce Website Development Plan Using Multidimensional Approach for Web Evaluation, Procedia - Social and Behavioral Sciences 115 ( 2014 ) 361 - 372

[13] Jung, E.S., Im, Y., 2015. Touchable area: an empirical study on design approach considering perception size and touch input behavior. Int. J. Ind. Ergon. 49, 21-30.

[14] Wang, C.M., Huang, C.H., 2015. A study of usability principles and interface design for mobile e-books. Ergon. 58 (8), 1253-1265.

[15] Sherman, R.C., End, C., Kraan, E., Cole, A., Campbell, J., Birchmeier, Z., Klausner, J., 2000. The Internet gender gap among college students: forgotten but not gone? CyberPsychol. Behav. 3 (5), 885-894.

[16] Ong, C.S., Lai, J.Y., 2006. Gender differences in perceptions and relationships among dominants of e-learning acceptance. Comput. Hum. Behav. 22 (5), 816e829 ; Huang, W.H.D., Hood, D.W., Yoo, S.J., 2013. Gender divide and acceptance of collaborative Web 2.0 applications for learning in higher education. Internet High. Educ. 16, 57-65

[17] Simon, S.J., 2001. The impact of culture and gender on web sites: an empirical study. Data Base Adv. Inf. Syst. 32, 18-37; Dittmar, H., Long, K., Meek, R., 2004. Buying on the inter-net: gender difference in on-line and conventional buying motivations. Sex Roles 50, 423-444 ; Cyr, D., Bonanni, C., 2005. Gender and website design in e-business. Int. J. Electron. Bus. 3, 565-582

[18] Darmaprawira, Sulasmi. 2002. Warna: Teori dan Kreativitas Penggunanya. Bandung: Penerbit ITB.

[19] Duncan, T. 2008, Integrated Marketing Communications European Edition. New York: Mc Grawhill, Inc 